International Journal of Linguistics, Literature and Culture
Available online at https://sloap.org/journals/index.php/ijllc/
Vol. 6, No. 1, January 2020, pages: 42-50
$\begin{aligned} & \text { ISSN: 2455-8028 } \\ & \text { https://doi.org/10.21744/ijllc.v6n1.821 }\end{aligned}$

\title{
Ideology Behind Character Value Discourse in a Balinese Pop Song
}

\author{
Komang Sri Marheni a \\ A. A. Ngurah Anom Kumbara ${ }^{b}$ \\ Ni Made Wiasti ${ }^{c}$ \\ Mayske Rinny Liando ${ }^{d}$
}

Article history:

Received: 09 September 2019

Accepted: 27 November 2019

Published: 10 January 2020

\section{Keywords:}

ajeg Bali;

Balinese pop song;

cultural industry;

discourse character value;

ideology;

\begin{abstract}
The research aims to uncover the ideology behind a discourse of character values in a Balinese pop song on the mass culture industry. The method used is qualitative-interpretative with a critical discourse analysis approach and semi-logical theory. Based on this approach, the study found four dominant ideology behind the discourse of character values in Balinese pop song, religious ideology, ajeg Bali or Bali stability, capitalism, and mass media. These four ideologies are driven by varying powers but are tied into the network of production as the growing industrialization of Balinese pop songs. The ideology puts the discourse of character values in a Balinese pop song as part of the mass-oriented culture industry. The implication, the discourse of character values arose drowned in Balinese pop songs as it followed the market demand.
\end{abstract}

International journal of linguistics, literature and culture (C) 2020. This is an open access article under the CC BY-NC-ND license (https://creativecommons.org/licenses/by-nc-nd/4.0/).

Corresponding author:

Komang Sri Marheni,

Kementerian Agama Kota Denpasar, Indonesia

Email address: rismako@yahoo.com

a Kementerian Agama, Denpasar, Indonesia

b Udayana University, Denpasar, Indonesia

c Udayana University, Denpasar, Indonesia

${ }^{\mathrm{d}}$ Manado State University, Manado, Indonesia 


\section{Introduction}

The Balinese pop song entered the recording industry first in mid-1970, which pioneered the Anak Agung Made Cakra alongside the band "Son of the Gods". The Album titled Kosir Dokar produced by Bali Stereo received a tremendous response from the public so that 900,000 copies were sold (Listibiya Province of Bali, 1986). One of the most popular song titles in the album is Bungan Sandat whose lyrics contain a lot of moral messages, also including the lyrics of several other songs in the album. According to Wijaya (2017), Bali's regional song as an embryo of Bali's pop song in addition to functioning as entertainment, also media become community character building. Therefore, moral messages tend to stand out in the lyrics of early Balinese pop songs. Moral values are the foundation of character development that refers to three components of good character, namely moral knowing, moral feeling, and moral action (Lickona, 1991).

In the era of globalization, the character's value has an important role for individuals and a cultural entity to confront a global paradox characterized by the identity of the master between homogeneity and plurality of Culture (Naisbitt, 1988; Ritzer \& Goodman, 2004; Ginaya, 2018; Astuti et al., 2019; Dasih et al., 2019). Balinese pop songs are certainly expected to function in the development of community characters to respond to globalization and affirm the cultural identity of Balinese in cultural pluralism. However, the character value discourse is increasingly difficult to find in the lyrics of Balinese pop songs after the 1990s, even more, romantic lyrics, humor, banal, and erotic more bestselling in the market. Although stillborn some Balinese pop songs that contain character values, but the acceptance is relatively less and depends on the quality of music, the quality of vocals, the popularity of singers, and the promotion.

The phenomenon suggests that Bali's pop song has entered the mass culture industry in a true sense. According to Lash (1990), the mass culture is engaged in the financial-economic and cultural economy as well, so that everything produced always gives birth to something ambiguous and paradoxically. Adorno (in Tester, 2003), even expressly states that following the culture of the masses in daily life, at the most favorable point only implications are simple, but at the most detrimental point can be an attack on the potential Enlightenment that is full of meaning. This criticism also occurs in the Bali pop song industry which is expected to play a role in community character building, it also has the potential to inhibit the transformation of character values. Especially when the existence of discourse character value in Balinese pop song has been negotiated so much with various ideology and power behind it.

Therefore, Bhaktin and Volosivov (in the titular title, et al., 2009) convey that discourse was something ideological. Barthes (1993) proposes a semiological analysis as a critique of ideology against various myths in mass culture. Discourse is a media creation myth, i.e. how to use through the signs of connotative that hides certain ideology, as well as to set the ideology so that it looks natural and what it is (taken for granted). Based on this theory, the discourse of character values in the Balinese pop song industry is seen as semiotic fact, namely the metaphor, connotative, and other double interpretation traits as communication systems that are loaded with cultural messages (Segers, 1978; Pradopo, 2003; Ratna, 2004; Junaidi, 2018). Based on the phenomenon, the purpose of this study is to uncover and explain what ideology operates behind the discourse of character values in Balinese pop songs.

\section{Materials and Methods}

The study uses a qualitative-interpretive method with a critical discourse analysis approach that emphasizes the linkage between language, ideology, and accompanying social change (Fasold, 1990; Sciffrin, 2007; Dewi et al., 2018). The primary Data of this research is the lyrics of Balinese pop song as the semiotic fact chosen purposively based on the criteria: (a) produced in Mass, (b) containing the discourse of character value, either explicitly or implicitly; (c) manufactured in different periods; and (d) its popularity in the community. Then, data on the existence of Bali's pop song was collected through observations on recording studios, distribution venues, concerts, and various media focused on the city of Denpasar. In-depth interviews have also been performed on recording studio owners, electronic media entrepreneurs, producers, creators, singers, and Balinese pop music connoisseurs. Data is analyzed in a descriptive-interpretive basis through two stages, namely ' thinking and reflecting ' and ' thinking of thought ' (Geertz, 1973). That is, the collection and interpretation of data do not stop at one stage of the use, but through a critical reflection of the empirical experience, political and power relations, and previous theoretical thinking.

Marheni, K. S., Kumbara, A. A. N. A., Wiasti, N. M., \& Liando, M. R. (2020). Ideology behind character value discourse in a balinese pop song. International Journal of Linguistics, Literature and Culture, 6(1), 42-50. 
The ideological concept rests on the view of Althusser (2010) that the intangible ideology of the real world, but the representation of individual imaginary relationships with the real relationships in which they live. Ideological positions are needed in the community so that they can interpret and change their existing conditions. A representation never appears naturally but is constructed by a certain ideology that is not separated from power relations within it. The ideological theory is used to analyze the power relations and knowledge that play behind the discourse of character values in Balinese pop songs as the mass culture industry. To uncover these ideologies, the semiology analysis of Barthes (1968) primarily criticized its ideological criticism of pop culture or mass culture. According to Barthes (1993), everything represented by the mass culture always carries a connotative sign to divide a particular message as the process of creation of myth. It is in every myth that the ideology of operation is associated with an association inherent in the Connotative language. These myths hid ideology, but also naturalized ideologies that seemed natural, objective, and formed a false awareness of Marx's or the unconsciousness of Freud's.

\section{Results and Discussions}

\subsection{The Relation of Discourse and Ideology}

Fowler (in Eriyanto, 2003) states that discourse is an oral communication or writing that contains beliefs, worldviews, and the experience of a speaker or ideology. Lexically, the concept of ideology encompasses all values, norms, philosophy, religious beliefs, sentiments, ethical rules, knowledge of the world or system of ideas used to rationalize, attack, and explain beliefs, actions, and Certain cultural controls. Because of its subjective nature, ideology cannot be known through direct observation, but it can be inferred according to the behavior of those who interact in various social systems (Kaplan \& Manners, 2002). Althusser (2010), states ideology is an imaginary relationship of individuals with the real world. Ideology has a material existence in the form of apparatus and practices that are believed and practiced by all members of the group, as well as reproduce the conditions and governance of the existing community. Ideology lives in the practice of small groups and represents themselves in imagery, objects of community use, and social organizations. Ideologies include assumptions, beliefs, and also system values that operate in social and cultural contexts (Hatim \& Munday, 2004; Mantra \& Widiastuti, 2018). Ideology was built to serve the importance of the ruling class as it gave legitimacy to a state that had no legitimacy (Suseno, 1999).

In the critical linguistic dimension, the whole social practice is seen as the text by Wittgenstein called ' Language games '. Lyotard (in Muntasyir, 2007) renders the language games concept as a paradigm for analyzing industrial society, among others. Firstly, that the rules do not legitimize themselves, but rather as objects of agreement, both explicit and implicit among the players. Secondly, if there is no rule, then there is no game. A change in rules without borders violates the nature of the game, a motion or speech is not satisfactory and is not included in the restricted games. Thirdly, every rule should be thought of as motion in a game. The opinion confirms that the rules or ideology are not to legitimize itself, but only as an object of the agreement for every actor involved in social practice. It is not important that ideology is true or not, because its truthfulness is precisely determined when all actors agree to speak and act by referring to the ideology.

Referring to Lyotard's opinion, the character's value discourse in Balinese pop songs is not ideologically neutral. Certain ideologies have built a discourse of character values that are poured in the lyrics of the Balinese pop song as a semiotic fact. The ideological may be the belief, ethical values, knowledge, world view, or subjective experience of the author. However, it also involves a dominant ideology that is absorbed from local, national, or global values that are believed to be true or at least affect the author's idea. These ideologies built a discourse of character values in Balinese pop songs involving various powers stored in the author's language games. The lyrics of Balinese pop songs are both as literary texts with specific grammatical structures, such as diction, sentences, themes, and messages, as well as the social text of structures, values, norms, cultures, powers, etc. are channels of discourse that channel The author's ideology. The character value in the Balinese pop song is merely a medium to build discourse in an integral relationship between language, knowledge, and Power (Piliang, 2005). Thus, the discourse of character value in Balinese pop song has a strong relation with ideological practices so undoubtedly it is revealed by positioning it as a semiotic fact. 


\subsection{Ideology behind the Discourse of Character Values}

Religious ideology. A discourse on the value of Hinduistic religious characters is found in several Balinese pop songs from the beginning to the present. The new Balinese pop song (2000-an) and contains religious values among others, Suksma Hyang Widhi ('Thank God') and Ratih-Kamajaya ('Goddess and God of Love in Hinduism') popularized by Dek Ulik. Both songs are quite popular among the Balinese pop song connoisseurs. This acceptance is closely related to the religious nature of the Balinese people as stated by Geertz (1992) and Vikers (1989), that Hindu teachings become the foundation of Balinese people in their daily religious life. The religiosity of Balinese people is what seems to be monitored by the Balinese pop song industry so almost never disappear from time to time.

The presence of religious discourse in the Balinese pop song has an ideological function to influence the consciousness of its connoisseurs who still make religious values as the basis of his life. This is in line with the ideological functions according to Althusser (2010), which is to alter, influence, and form the community's consensus in the practice of discourse. In the context of the mass cultural industry, the presence of religious discourse is certainly important to influence consumer awareness of Balinese pop songs that are the majority of the Hindu religion. The operation of religious ideology in the production of character value discourse is not solely due to the substance of value built, but precisely its function in establishing a meaningful exchange between the owner of the recording studio, producer, and audience in relation to Industry. This ideology is channeled in the lyrics of the religious charged songs as a semiotic sign that builds religious significance in the interwoven discourse of character values intact and solid.

Balinese ideology of Ajeg. Bali. Ajeg Discourse began to be formulated when the event of the Bali bombing I, 12 October 2002, and its influence soon spread to all walks of Bali (Wijaya, 2004). Ajeg Bali was then interpreted variably because this discourse was born suddenly as a new awareness of the socio-cultural conditions facing the people of Bali. Atmadja (2010), in response to the death of Bali's discourse on the detriment of Balinese identity because of the domination of migrants, the influence of modernization and globalization. Wijaya (2004), saw this discourse as a struggle between exclusivity and commercialization due to the openness of the Balinese community in response to the rush of globalization and modernization. Meanwhile, Triguna (1994), is to interpret ajeg Bali as an ideology of resistance against newcomers that tend to be more competitive in seizing economic sources.

Ajeg Bali has built a myth (a Barthes ideology) channeled in the various discourse, including through the lyrics of Balinese pop song. It can be referenced in several Balinese pop song titles that emphasize the importance of preserving the nature and culture of Bali, such as the Bali Sutrepti ('The Orderly Bali') by I Gde Dharna, Taksu ('Inner power') by Suryawan; and Ngassumariang Bali ('Keep Bali') the opening song and closing local television show ' Bali TV '. Although Ajeg Bali itself has a diverse and ambiguous meaning, the lyrics of the Balinese pop song set special categories on the community about the meaning of Bali ajeg. Even some people interpret that Bali's pop song is a real effort in realizing Ajeg Bali. In this relationship, Ajeg Bali managed to play its ideological function to influence and build awareness of Balinese people to receive Balinese pop songs as part of the real effort to implement the Bali ajeg value. Whereas behind it, this discourse also formed a community as a consumer of Balinese pop songs which of course benefit the Balinese pop song industry.

Capitalist ideology. Balinese pop songs since the era of Anak Agung Made Cakra (1970-an) have entered industrialization involving the network of power cultures, capitals, and distribution networks. The development of Bali's pop song has been formed by the effect of changing technology, economics, and the existence of new cultures in society (Frith, 1988; Frith \& Goodwin, 2006). The industrialization of Balinese pop songs is not undeniable to be an infiltration of capitalist ideology that puts capital as the main driving force of socio-cultural order in the production relationship and production tools by Marx called Mode of Production (Suwija, 2016). The capitalist ideology that emphasizes capital multiplication - ' Money making Money ' - is a defining production, distribution, and consumption of Balinese pop songs. Thus, Balinese pop songs have become a commodity that is more determined by the exchange rate, rather than a value (Lash, 1990).

The hegemony of capitalist ideology is characterized by the presence of recording studios of Balinese pop songs, among others Bali Record (a change from Bali Stereo), Maharani Record, Aneka Record, Kaplug Dadi Record, and Januadi Record. The technology used to produce Balinese pop songs is also increasingly sophisticated following the development of the Times. The marketing of Balinese pop songs through outlets is done by using capital networking that producers and distributors alike are capital owners. Capitalist ideology became a major force in the production of Balinese pop songs that fully followed the market mechanics. The creators of the Balinese pop song seem to have no more freedom to channel their own ideological because they are forced to serve the capital owner's ideology in the

Marheni, K. S., Kumbara, A. A. N. A., Wiasti, N. M., \& Liando, M. R. (2020). Ideology behind character value discourse in a balinese pop song. International Journal of Linguistics, Literature and Culture, 6(1), 42-50.

https://doi.org/10.21744/ijllc.v6n1.821 
interest of his business. The songs produced were the songs that were desired by the market so that the vocal quality, the popularity of singers, musicality, and the packaging of the song became more important than the value or the song's mandate. The discourse of character values is produced in several songs, but technical and aesthetic factors are more noted in the production to be acceptable to consumers. That is, capitalist ideology has positioned the market as the main orientation or market-oriented so that the discourse of character value in Bali's pop song is always negotiated with the market mechanics.

Mass Media ideology. Along with the industrialization of the Balinese pop song, the Balinese people have been transformed as a consumer community that became a potential market in the distribution of Balinese pop songs. Piliang (1998), stated that in a consumer society, at least formed three forms of power that operate behind the production and consumption of aesthetic objects, namely capital Power, producer and mass media. In industrialization of Balinese pop song, capital Power owned by the owner of the recording studio, the power of the producer is directly owned by the art actors, such as songwriters, singers and music arrangers, while the mass media power owned mass media owners. When capital Power has more role in the context of the financial economy, the mass media power is more engaged in the cultural economy. Both of these powers interact dialectically with producers as the culprit.

The continuity of the production and popularity of Balinese pop songs is not separated from the role of mass media. When it first appeared in 1970, the radio played an important role in spreading Balinese pop songs to the public. From the years from 1990 to 2000, Balinese pop songs appeared in local television broadcasts such as TVRI Bali ('government-owned') and Bali TV ('Local private stations'), and other local television shows, The Gods TV (2007), and BMC (Bali Music Channel). (2010) who also broadcast the Bali pop songs program. Later, Balinese pop songs began to penetrate mobile digitally in the form of MP3 and YouTube. The mass media had a major role in the propagating of Bali's pop songs including popularizing its singing through infotainments that contributed to the community's lifestyle. In the mass media industry, the character value discourse in Balinese pop song is as if to find his place back because it is also broadcast through television channels, radio, and the Internet. Nevertheless, this can be viewed as a mass media power positioning effort through the creation of the myth that they have participated in developing Balinese pop songs. Through this myth, mass media entrepreneurs can reap public sympathies as a form of partiality on Balinese pop songs correlated with cultural capital. If public awareness to witness the program of Bali pop song broadcasts can be captured, then the mass media entrepreneurs will receive various financial benefits such as the inclusion of advertisements.

\subsection{The Implications of Ideological Practice}

The ideological practice behind a discourse of character values in a Balinese pop song marks the operation of various power relationships that move on the financial and cultural economy. In the ideological context, the character value discourse is always negotiated with the power behind the production of Balinese pop songs. As part of the mass culture industry, the Mobilizer's power is a knot on the capitalist (recording studio owner) who produces and distributes Balinese pop songs to consumers. Capitalist power provides space to producers (creators, singers, and musicians of Balinese pop songs) to work and benefit from his works. The interaction between capitalists and producers determines the value of Balinese pop songs in the market mechanics and hence, the songs produced must follow the market demand. The mass Media also became the deciding power to the dissemination of Balinese pop song to the people who besides the economic interests of media owners, also aims to transform certain cultural values to the community.

These three powers wrestle in the ideological practice behind the discourse of character values in Balinese pop songs as the mass culture industry. The implication, the discourse of the Timbul-tenggelam character in Balinese pop songs is seen in every developmental phase. In the period from 1970 to 1990, the character's value discourse tends to be dominant in Balinese pop songs because the connoisseur community puts the depth of the song in the sense, compared to the quality of the music and the singing vocals. It proved that with musical accompaniment that is technically quite simple, but the condensed songs are worth the character get the extraordinary acceptance of the community. Entering the 1990-2000 era, music technology has been used in the production of Balinese pop songs, resulting in more beautiful musical and vocal effects. In addition, they also emerged new singers with good vocal qualities such as Widi Widiana, Panji Kuning, Yan Srikandi, Dek Ulik, and others. The lyrics of romantic nuance, melancholy, humor, even erotic dominating the pop song Bali and acceptable to the public, although the song that reveals the value of some characters are also still produced. Entering the 2000 era until now, the genre of the song hard rock, ethnic, and dangdut also appeared, but the discourse of character value is increasingly receding in the 
Balinese pop song industry. That is, aesthetic value is the basis of consideration that is more important in producing Balinese pop songs, rather than the didactic and symbolic value to be conveyed through song lyrics.

The resulting sinking of the character value in a Balinese pop song is certainly not separated from the power behind Bali's pop track industry. The discourse of character value in Balinese pop song has become a functioning ideology channel in the creation of a myth of mass culture that seems to present enlightenment for the community, but it is actually merely serving the importance of power behind it. When the community (consumers) still prioritize the depth of meaning, the songs that will be the character values are undoubtedly continuously produced. However, when the community began to put music, vocals, and singers ' popularity as a representation of the musical choice, the song's meaning was increasingly neglected. The socio-cultural situation is also an important consideration in the production of Balinese pop song, such as when the Bali Ajeg discourse strengthened, then the songs that are the nuance of the Balinese Ajeg Lively is produced. This is in line with Abdullah (2001), that the reader as a meaninggiver will recommit the text according to the variables of the space, time, and socio-cultural background that have committed the birth of different readings, understandings, and judgments. The implication that the ideologies behind a discourse of character values prompted a public reception shift against the meaning of Balinese pop song from the Didactics-symbolic to the technical-aesthetic.

\section{Conclusion}

Industrialization Balinese pop songs have put the discourse of character values as ideological channels for the power of capitalists, producers, and mass media to form the acceptance of the community (consumers) within the sphere of the financial and cultural economy. Religious ideology is behind the discourse of the character value to meet the market tastes of the majority of consumers of the Hindu religion. Bali Ajeg Ideology builds a discourse of character values in accordance with the principles of Bali Ajeg because the issue has a strong influence on the psychology of Balinese people as the main consumer of Balinese pop songs. Capitalist ideology puts the discourse of character values in Balinese pop songs on the production, consumption, and distribution frameworks oriented towards the market mechanisms. The ideology of mass media positioned the discourse of character values as a channel of financial interests of the owner of the mass media as well as the importance of establishing cultural capital through a discourse of alignments on local cultures. In these ideological relationships, the discourse of character value arises in the Balinese pop song industry and gives the consumer greater power to determine its meaning so that it is not uncommon to mean ambiguous and paradoxical.

\section{Conflict of interest statement}

The authors declared that they have no competing interests.

\section{Statement of authorship}

The authors have a responsibility for the conception and design of the study. The authors have approved the final article.

\section{Acknowledgments}

We would like to express our gratitude to Prof. Dr. A.A. Anom Kumbara, the Doctorate Program Coordinator of the Cultural Study Program for his contribution to completing the author study, and all informants who gave lots of contribution for this research.

Marheni, K. S., Kumbara, A. A. N. A., Wiasti, N. M., \& Liando, M. R. (2020). Ideology behind character value discourse in a balinese pop song. International Journal of Linguistics, Literature and Culture, 6(1), 42-50. 


\section{References}

Abdullah, I. T. (2001). Resepsi Sastra: teori dan Penerapannyall dalam Jabrohim. Metodologi Penelitian Sastra.

Althusser, L. (2010). "Ideology and Ideological State Apparatuses (Notes towards an Investigation)"(1970). Cultural theory: an Anthology, 204-22.

Astuti, N. N. S., Ginaya, G., \& Susyarini, N. P. W. A. (2019). Designing Bali tourism model through the implementation of tri hita karana and sad kertih values. International journal of linguistics, literature and culture, 5(1), 12-23. https://doi.org/10.21744/ijllc.v5n1.461

Atmadja, N. B. (2010). Ajeg Bali: gerakan, identitas kultural, dan globalisasi. Penerbit \& distribusi, LKiS.

Barthes, R. (1968). Elements of semiology. Macmillan.

Barthes, R. (1993). Mythologies. London: Vintage.

Dasih, I. G. A. R. P., Triguna, I. B. G. Y., \& Winaja, I. W. (2019). Intercultural communication based on ideology, theology and sociology. International Journal of Linguistics, Literature and Culture, 5(5), 29-35. https://doi.org/10.21744/ijllc.v5n5.738

Dewi, I. G. A. A. O., Dewi, I. G. A. A. P., Kustina, K. T., \& Prena, G. D. (2018). Culture of tri hita karana on ease of use perception and use of accounting information system. International Journal of Social Sciences and Humanities, 2(2), 77-86. https://doi.org/10.29332/ijssh.v2n2.131

Eriyanto. (2003). Media dan konflik Ambon: media, berita, dan kerusuhan komunal di Ambon, 1999-2002. Kantor Berita Radio $68 \mathrm{H}$.

Fasold, R. W. (1990). The sociolinguistics of language (Vol. 2). Blackwell Pub.

Frith, S. (1988). Music for pleasure: essays in the sociology of pop (p. 101). New York: Routledge.

Frith, S., \& Goodwin, A. (2006). On record: rock, pop and the written word. Routledge.

Geertz, C. (1973). The interpretation of cultures (Vol. 5019). Basic books.

Geertz, C. (1992). Tafsir Kebudayaan, terj. Francisco Budi Hardiman. Yogyakarta: Kanisius.

Ginaya, G. (2018). The Balinese calendar system: From its epistemological perspective to axiological practices. International journal of linguistics, literature and culture, 4(3), 24-37.

Hatim, B. A., \& Munday, J. (2004). Translation: An advanced resource book. Routledge.

Junaidi, L. M. (2018). Stereotypes as the Ideology of Feminism in Novels Authorized by Indonesian Female Authors. International Journal of Linguistics, Literature and Culture, 4(1), 1-15.

Kaplan, D., \& Manners, R. A. (2002). The Theory of Culture. Terj. Landung Simatupang. Teori Budaya. Yogyakarta.

Lash, S. (1990). Postmodernist sociology.

Lickona, T. (1991). Educating for character (New York, Bantam). McCI ET nAN, BE (1992) Schools and the Shaping of Character: moral education in America, 525-543.

Listibya Propinsi Bali Seksi Musik. (1986). Inventarisasi Seniman Musik Diatonis Daerah Bali Th. 1985. Denpasar: Proyek Penggalian/Pemantapan Seni Budaya Klasik dan Baru Tahun 1986/1987.

Mantra, I. B. N., \& Widiastuti, I. A. M. S. (2018). Structural analysis and religiosity of Balinese song lyrics. International Journal of Linguistics, Literature and Culture,4(4), 69-75. https://doi.org/10.21744/ijllc.v4n4.268

Mustansyir, R. (1987). Filsafat analitik: sejarah, perkembangan, dan peranan para tokohnya. Rajawali Pers.

Naisbitt, J., \& Rolandini-Martelli, A. (1988). Mega trends: Le dieci nuove tendenze che trasformeranno la nostra vita. Sperling\&Kupfer.

Piliang, Y. A. (1998). Sebuah dunia yang dilipat: realitas kebudayaan menjelang milenium ketiga dan matinya posmodernisme. Mizan Pustaka.

Piliang, Y. A. (2005). Transpolitika: Dinamika Politik di dalam Era Virtualitas. Jalasutra.

Pradopo, R. D. (1994). Prinsip-prinsip kritik sastra. Cet. V.

Ratna, I. N. K. (2004). Teori, metode \& teknik penelitan sastra: dari strukturalisme hingga postrukturalisme: perspektif wacana naratif. Pustaka Pelajar.

Ritzer, G., \& Goodman, D. J. (2004). Modern Sociological Theory, terj. Alimandan, Teori Sosiologi Modern, Jakarta: Prenada Media.

Schiffrin, D. (2007). Ancangan kajian wacana. Pustaka Pelajar.

Segers, R. T. (1978). Studies in Semiotics: The evaluation of literary texts (Doctoral dissertation, Rijksuniversiteit te Utrecht).

Suseno, F. M. (1999). Pemikiran Karl Marx: Dari Sosialisme Utopis ke Perselisihan Revisionisme. Jakarta: PT Gramedia. 
Suwija, I. N. (2016). A study on educational value of national character towards Balinese traditional song text. International Journal of Linguistics, Literature and Culture, 2(3), 133-143.

Tester, K. (2003). Seri Cultural Studies, Media, Budaya, dan Moralitas.

Triguna, G. Y. (1994). Pergeseran dalam Pelaksanaan Agama Menuju Tattwa” dalam I Gde Pitana, ed, 1994. Dinamika Masyarakat dan Kebudayaan Bali, BP, Denpasar Bali.

Vickers, A. (1989). Bali: a paradise created. Ringwood. Victoria: Penguin.(An excellent historical analysis of how Europeans set about imagining Bali.).

Wijaya, I. M. H. (2017). Revitalisasi gending rare dalam mata pelajaran agama hindu untuk mengantisipasi penyimpangan perilaku pada anak (Studi Kasus di Kelas V SDN 5 Batungsel). Jurnal Penelitian Agama Hindu, 1(2), 319-326. http://dx.doi.org/10.25078/jpah.v1i2.259

Wijaya, N. (2004). Melawan Ajeg Bali: Antara Eksklusivitas dan Komersialisasi. Tantular Jurnal Ilmu Sejarah, 2, 174.

Marheni, K. S., Kumbara, A. A. N. A., Wiasti, N. M., \& Liando, M. R. (2020). Ideology behind character value discourse in a balinese pop song. International Journal of Linguistics, Literature and Culture, 6(1), 42-50. 


\section{Biography of Authors}

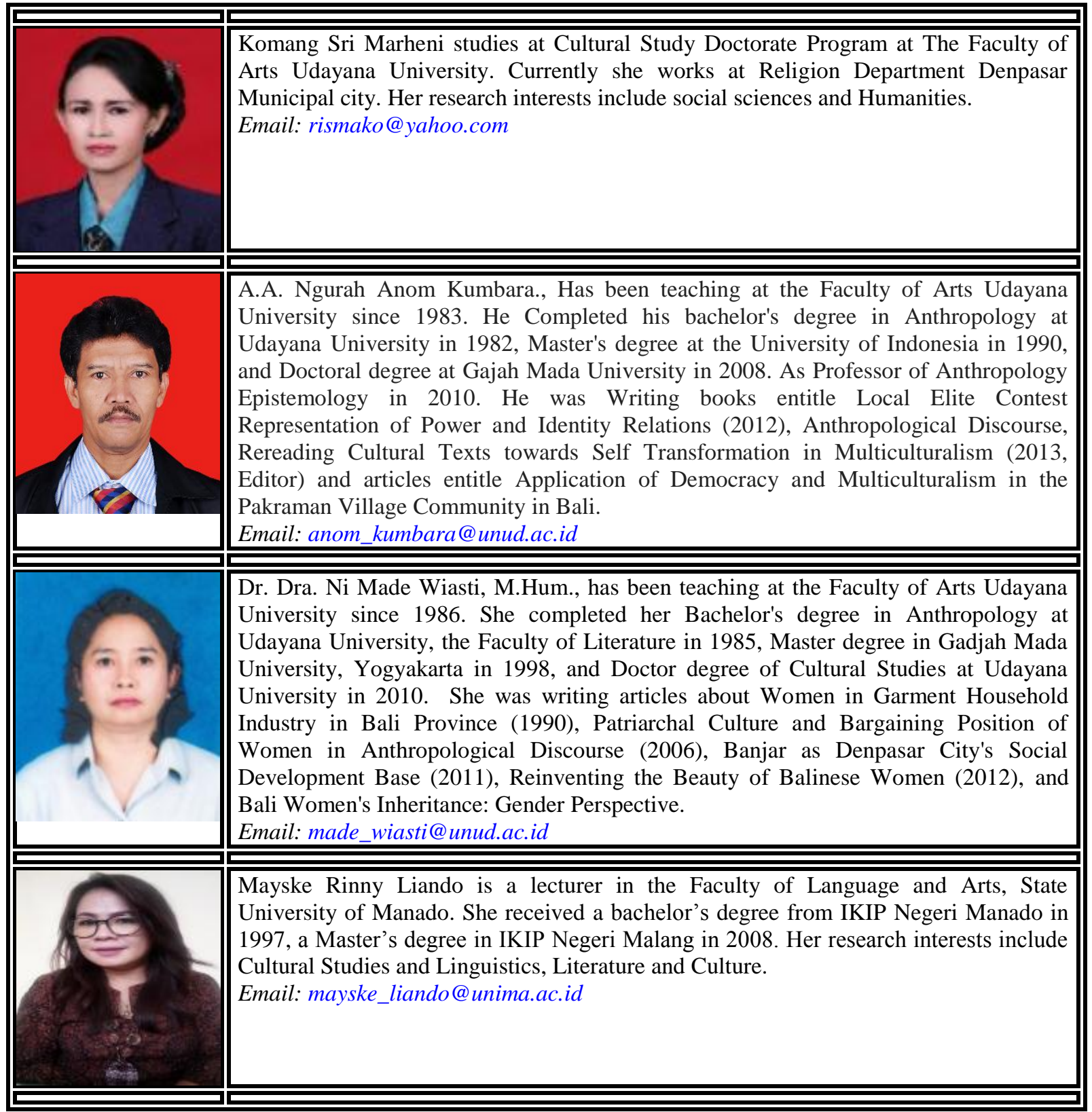

